\title{
THE EVALUATION OF GROWTH DYNAMICS OF LONICERA KAMTSCHATICA CLONES
}

\author{
J. Matuškovič, T. Pokorná-Juríková \\ Received: July 31, 2006
}

\begin{abstract}
MATUŠKOVIČ, J., POKORNÁ-JURÍKOVÁ, T.: The evaluation of growth dynamics of Lonicera kamtschatica clones. Acta univ. agric. et silvic. Mendel. Brun., 2007, LV, No. 2, pp. 53-58

Artickle deals with the evaluation of growth dynamics of selected set of clones Lonicera kamtschatica in the conditions of Nitra. We measured the growth of the shrubs twice a year (in spring and autumn) during 2003-2005. Within all clones 5 shrubs were evaluated. On the basis of the obtained results we can claim the highest increase of height in case of LKL 21 followed by clones LKL 16 and LKL 5. The lowest growth increase was typical for LKL 58 and LKL 66.

In term of statistical evaluation the year can be considered as a statistically significant factor forming a growth intensity of clones during 2003-2005. The effect of year on growing processes is strong $\left(\varepsilon^{2}=\right.$ $0.96)$ while the participation of year with clone influenced the growth increase in medium size $\left(\varepsilon^{2}=\right.$ 0.42). LKL 21 and LKL 58 in comparison with other clones are the most disperatable in term of growth increase. Within mentioned clones statistically significant differences were recorded in 7 evaluated pairs. In the same way LKL 42 is very different from another clones as well. On the basis of all provided analysis the tested clones from point of wiev perspectivity of planting can be set up in the following order: LKL 21, LKL 16, LKL 5, LKL 42, LKL 49, LKL 96, LKL 6, LKL 60, LKL 66 and LKL 58.
\end{abstract}

Lonicera kamtschatica, clones, growth dynamics, year, repeatings

Honeyberry (Lonicera kamtschatica) belongs to the popular berry crop of the Far East. Honeyberry's popularity among a native inhabitans has been increasing because of his valuable traits-nutritional value of fruits (a hight amount of ascorbic acid, potassium and polyphenolic compounds), early ripening (14 days before strawberry), exceptional hardiness and easy cultivation (Jušev and Plekhanova, 1997). Pokorná, Podoláková and Matuškovič (2002) noticed that the biological value of fruits consists in a hight amount ascorbic acid that ranges from $63.13 \mathrm{mg} / 100 \mathrm{~g}$ of fresh weight up to $86.95 \mathrm{mg} / 100 \mathrm{~g}$ and the content of potassium achieved in average $11575 \mathrm{mg} / \mathrm{kg}$.

The introduction of this this new fruit species requires a selection of the new adaptable clones with a tasty berry, regular yield and a high level of of ascorbic acid and polyphenolic compounds (especially anthocyanins, kvercetin, isokvercetin and rutin)
(Plekhanova, 2000). The obtained set of clones have to be evaluated in growth dynamics, phenological characteristics, chemical composition of fruits and another very important attributes (Matuškovič, 2003).

Growth dynamics is one of the important characteristics pointed to the perspective clones and helping us specify only the most suitable for the further cultivation and propagation.

Growth dynamics is influenced by growing conditions-way of the cultivation, planting distance and agrotechnics. Growing processes are clearly related to flowering and production of shrubs (Plekhanova, 1986). Relation between growth and production is realized under very important factors such as water, sunshine, light and agrotechnics (Matuškovič and Paulen, 2001). 


\section{MATERIAL NAD METHODS}

10 clones of honeyberry (Lonicera kamtschatica) LKL 5, LKL 6, LKL 16, LKL 21, LKL 42, LKL 49, LKL 58, LKL 60, LKL 66, LKL 96 in 5 repeatings during 3 years (2003-2005) were measured in the natural conditions of Nitra. Selected clones represented by nursery plants from Klčov were planted in autumn 2002. Irrigation and fertilizators were not be applicated. All measurements were carried out twice a year (in spring and autumn), the height of shrubs were noticed in meters. For the objective evaluation of growth increase we used the growth index. The growth index formulated ration between growth increase during the observed period 2003-2005 and the basic heights of shrubs at the begging of our measurements. Obtained results were given into the table forms and in the following they were statistically evaluated. We examined the statistical significance of clones, repeatings and year on the growth intensity of shrubs. For the verification of differences at the beggining of our experiments we used a two-factor analysis of variance (procedure ANOVA). During 2003-2005 for the evaluation of year influence we used a multifactorial analysis of variance (procedure MANOVA) and Boxing M-test with Levene test for equality of variances. For the determination of year influence on the increase of biomass it was examined a coeficient $\varepsilon^{2}$.

On the statistically significant differences between mean values of growth increase pointed two- sample $\mathrm{t}$ - test for significance level $\alpha=0.05$. All mentioned statistical procedures were provided in the STATGRAPHIC programe.

\section{RESULTS}

In term of evaluation of differences in growth dynamics of clones and the determination of the year influence and repeatings it is necessary to know the growth dynamics of all evaluated shrubs. The aim of this artickle was to find out the growth increase of selective clones. It can be helpful to state a proper spacing and shape of shrub's habit. Results of our measurements summarizing growth increase of clones during 2003-2005 are given in the table I (the highest values are underlined).

I: Mean values of growth increase for the clones Lonicera kamtschatica during 2003-2005

\begin{tabular}{|l|c|c|c|c|c|c|c|c|c|c|}
\hline clones & $\begin{array}{c}\text { LKL } \\
\mathbf{5}\end{array}$ & $\begin{array}{c}\text { LKL } \\
\mathbf{6}\end{array}$ & $\begin{array}{c}\text { LKL } \\
\mathbf{1 6}\end{array}$ & $\begin{array}{c}\text { LKL } \\
\mathbf{2 1}\end{array}$ & $\begin{array}{c}\text { LKL } \\
\mathbf{4 2}\end{array}$ & $\begin{array}{c}\text { LKL } \\
\mathbf{4 9}\end{array}$ & $\begin{array}{c}\text { LKL } \\
\mathbf{5 8}\end{array}$ & $\begin{array}{c}\text { LKL } \\
\mathbf{6 0}\end{array}$ & $\begin{array}{c}\text { LKL } \\
\mathbf{6 6}\end{array}$ & $\begin{array}{c}\text { LKL } \\
\mathbf{9 6}\end{array}$ \\
\hline $\begin{array}{l}\text { mean } \\
\text { increase in } \\
\mathbf{2 0 0 3}\end{array}$ & 0.088 & 0.070 & 0.128 & $\underline{0.198}$ & 0.124 & 0.068 & 0.038 & 0.090 & 0.092 & 0.086 \\
\hline $\begin{array}{l}\text { mean } \\
\text { increase } \\
\text { in 2004 }\end{array}$ & 0.116 & 0.136 & 0.116 & $\underline{0.198}$ & 0.068 & 0.160 & 0.052 & 0.110 & 0.072 & 0.106 \\
\hline $\begin{array}{l}\text { mean } \\
\text { increase } \\
\text { in 2005 }\end{array}$ & 0.180 & 0.128 & $\underline{0.186}$ & 0.102 & 0.170 & 0.104 & 0.104 & 0.090 & 0.050 & 0.104 \\
\hline $\begin{array}{l}\text { mean } \\
\text { increase } \\
\text { during } \\
\mathbf{2 0 0 3 - 2 0 0 5}\end{array}$ & $\mathbf{0 . 1 2 8}$ & $\mathbf{0 . 1 1 1}$ & $\mathbf{0 . 1 4 3}$ & $\mathbf{0 . 1 6 6}$ & $\mathbf{0 . 1 2 7}$ & $\mathbf{0 . 0 6 4}$ & $\mathbf{0 . 0 6 4}$ & $\mathbf{0 . 0 9 6 7}$ & $\mathbf{0 . 1 2 4 7}$ & $\mathbf{0 . 0 9 8 7}$ \\
\hline
\end{tabular}

From the table I is evident the highest value of mean growth increase in LKL 21 (0.198 m) during the period spring-autumn 2003. The second position in order had LKL 16 (mean increase of height $0.128 \mathrm{~m}$ ), the third in order was LKL 42 with mean value of growth increase 0.124 meters. The slowest growth was typical for the LKL 58 with mean growth increase 0.038 meters.

In 2004 it was confirmed the highest growth intensity of LKL 21 with the same value of growth increase as in 2003. This clone was following by LKL 49 (with the mean increase of height 0.160 meters) and LKL 6 (with the mean increase $0.136 \mathrm{~m}$ ). The lowest value of growth increase was noticed in LKL 58 which is in agreement with the results of the previous year.

In 2005 the highest growth intensity was characteristics for LKL 16 with the mean growth intensity 0.186 meters followed by LKL 5 (mean increase $0.180 \mathrm{~m}$ ) and LKL 42 (mean increase $0.170 \mathrm{~m}$ ). The lowest value of average growth increase, represented by 0.050 meters, was achieved in LKL 66 .

Summarize the growth rate of all clones during 2003-2005 we can claim the highest increase of height in case of LKL 21. This value takes 2.49 meters during 3 years. The second place was represented by LKL 16 
with growth increase 2.15 meters and the third position had LKL 5 with increase 1.92 meters during 20032005. From the evaluated set of clones the lowest growth intensity was typical for LKL 58 with the increase of height 1.06 meters during 3 years of evaluation.

For the objective evaluation of growth rate growth index must be also taken into consideration.

II: Growth index of the individual clones

\begin{tabular}{|c|c|}
\hline evaluated clones & growth index in \% \\
\hline LKL 5 & 123.28 \\
\hline LKL 6 & 122.1 \\
\hline LKL 16 & 128.1 \\
\hline LKL 21 & 160.1 \\
\hline LKL 42 & 91.86 \\
\hline LKL 49 & 117.03 \\
\hline LKL 58 & 79.21 \\
\hline LKL 60 & 91.91 \\
\hline LKL 66 & 74.51 \\
\hline LKL 96 & 86.05 \\
\hline
\end{tabular}

On the basis of growth indexes given in the table II the evaluated set of clones can be ranked in the following order: LKL 21 (160.1\%), LKL 16 (128.21\%) and LKL $5(123.28 \%)$. The last places were taken by LKL 66 (74.51\%) and LKL 58 (79.21\%).

Two-factor analysis of variance (procedure ANOVA) was used for the verification of differences in growth increase of shrubs at the beggining of our observations in spring of 2003. It was tested the statistical significance of 2 factors of variability-clones and repeatings. On the basis of the observed results it was not be proved statistically significance differences between growth increase of individual clones $(\mathrm{P}=$ $0.07)$ and repeatings $(\mathrm{P}=0.952)$.

Statistical significance of year during 2003-2005 on the growth intensity of clones was evaluated by multifactorial analysis of variance (procedure MANOVA). Results of evaluation showed on the statistical significance of year from point of view forming biomass of clones during 2003-2005 for significance level $\alpha=$ 0.05 . The results of statistical evaluation are given in the table III.

III: Statistical evaluation of the effect of year and the interaction year-clone

\begin{tabular}{|l|c|c|c|}
\hline Source of variability & F- crit & F- stat & $\boldsymbol{\varepsilon}^{\mathbf{2}}$ \\
\hline year & 0.0398 & 3.048 & 0.96 \\
\hline clone* year & 0.1926 & 3.1316 & 0.42 \\
\hline
\end{tabular}

F- crit - F critical value, F- stat - F statistic value

Results in the table III lead us to statement that year had a strong effect on the growth increase of the individual clones of Lonicera kamtschatica $\left(\varepsilon^{2}=0.96\right)$ while interaction clone with year participle on the variability in medium size $\left(\varepsilon^{2}=0.42\right)$. On the statistically significant influence of year pointed the results of Box $\mathrm{M}$ - test $(\mathrm{P}=0.02)$ as well. On the basis of this test hypothesis presumed equality of the covariance equation can be refused. In the same way the results of Levene test showed on the disparity of differences from medians. All mentioned analysis focused on the statistical significance of year forming a growth rate of clones.

In the further evaluation we paid our attention to the testing of differences between mean growth increase of clones during 2003-2005. Results of evaluation are summarized in tables IV-VII.

From results of two-sample $\mathrm{t}-$ test is evident that in the most cases LKL 21 and LKL 58 were participated on the variability of the evaluated set of clones Lonicera kamtschatica. In the case of both clones statistically significant differences were recorded in 7 pairs of clones. In LKL 21 there were evaluated the following pairs, in which we recorded statistically sig- nificant differences for significance level $\alpha=0.05$ : LKL 21-LKL 5, LKL 21-LKL 6, LKL 21-LKL 49, LKL 21-LKL 58, LKL 21-LKL 60, LKL 21-LKL 66, LKL 21-LKL 96. With the LKL 58 we found out the following statistically significant combinations: LKL 58- LKL 5, LKL 58-LKL 16, LKL 58-LKL 21, LKL 18-LKL 42, LKL 58-LKL 49, LKL 58-LKL 60, LKL 58-LKL 96. From this view is clear that it was also determined statistically significant differences between LKL 21 and LKL 58. As it has been mentioned before LKL 21 and LKL 58 are contradicted each other in growth intensity. For the LKL 21 is characteristics the most dynamics growth while for the LKL 58 is typical the lowest increase of height during 2003-2005. Therefore the clone LKL58 can be recomended for the planting of miniature forms. Equally in case of LKL 42 statistically significant differences are evident in 6 pairs of combinations (LKL 42-LKL 49, LKL 42-LKL 58, LKL 42-LKL 60, LKL 42-LKL 66, LKL 42-LKL 96, LKL 42-LKL 5).

LKL 42 statistically significantly differed from LKL 58 but tested differences between mean values of growth increase LKL 58 and LKL 21 can not be considered as statistically significant. 
In case of other clones we found out statistically significant differences in 3 (LKL 5, LKL 6, KLK 58, LKL 66) or 4 tested pairs (LKL 16, LKL 49, LKL 96).

On the basis of all provided analysis the tested clones from point of view perspectivity of planting can be set up in the following order:
LKL 21, LKL 16, LKL 5, LKL 42, LKL 49, LKL 96, LKL 6, LKL 60, LKL 66 and LKL 58.

Further studies of Lonicera kamtschatica clones could open the door for the acceptance of this lessknown fruit in Slovak horticultural comodities.

IV: Testing of significance of differences in mean increase values for plants height of clone 5 and 6 in combination with other clones

\begin{tabular}{|c|c|c|c|c|c|c|c|c|c|}
\hline \multirow{10}{*}{ LKL 5} & clones & $\mathrm{x}(1)$ & $\mathrm{x}(2)$ & $\mathrm{t}$ (stat) & $\mathrm{P}(1)$ & $\mathrm{t}($ crit 1$)$ & $\mathrm{P}(2)$ & $\mathrm{t}($ crit 2) & Significance \\
\hline & LKL 6 & 0.42 & 0.374 & 2.009 & 0.0328 & 1.77 & 0.066 & 2.16 & - \\
\hline & LKL 16 & 0.42 & 0.488 & 1.668 & 0.0596 & 1.77 & 0.119 & 2.16 & - \\
\hline & LKL 21 & 0.42 & 0.28 & 2.955 & 0.0056 & 1.77 & 0.011 & 2.16 & $*$ \\
\hline & LKL 42 & 0.42 & 0.51 & 4.381 & 0.0004 & 1.77 & 0.0007 & 2.16 & $*$ \\
\hline & LKL 49 & 0.42 & 0.421 & -0.037 & 0.4854 & 1.77 & 0.97 & 2.16 & - \\
\hline & LKL 58 & 0.42 & 0.348 & 2.193 & 0.0236 & 1.77 & 0.047 & 2.16 & $*$ \\
\hline & LKL 60 & 0.42 & 0.426 & 0.192 & 0.4253 & 1.77 & 0.851 & 2.16 & - \\
\hline & LKL 66 & 0.42 & 0.394 & 0.646 & 0.2649 & 1.77 & 0.529 & 2.16 & - \\
\hline & LKL 96 & 0.42 & 0.443 & 1.226 & 0.1211 & 1.77 & 0.2428 & 2.16 & - \\
\hline \multirow{8}{*}{ LKL 6} & LKL 16 & 0.367 & 0.512 & 4.267 & 0.00039 & 1.76 & 0.0008 & 2.12 & $*$ \\
\hline & LKL 21 & 0.367 & 0.484 & 3.352 & 0.00237 & 1.76 & 0.0047 & 2.12 & $*$ \\
\hline & LKL 42 & 0.367 & 0.507 & -7.155 & 0.00245 & 1.76 & 0.0005 & 2.12 & - \\
\hline & LKL 49 & 0.367 & 0.411 & 1.284 & 0.1099 & 1.76 & 0.2199 & 2.12 & - \\
\hline & LKL 58 & 0.367 & 0.336 & 0.853 & 0.2039 & 1.76 & 0.0408 & 2.12 & - \\
\hline & LKL 60 & 0.367 & 0.417 & 1.5108 & 0.0765 & 1.76 & 0.153 & 2.12 & - \\
\hline & LKL 66 & 0.367 & 0.389 & 0.8198 & 0.213 & 1.76 & 0.4261 & 2.12 & - \\
\hline & LKL 96 & 0.367 & 0.437 & 2.9114 & 0.0056 & 1.76 & 0.0114 & 2.12 & $*$ \\
\hline
\end{tabular}

$\mathrm{V}$ : Testing of significance of differences in mean increase values for plants height of clone 16 and 21 in combination with other clones

\begin{tabular}{|c|c|c|c|c|c|c|c|c|c|}
\hline \multirow{8}{*}{ LKL 16} & clones & $\mathrm{x}(1)$ & $\mathrm{x}(2)$ & $\mathrm{t}$ (stat) & $\mathrm{P}(1)$ & $\mathrm{t}($ crit 1$)$ & $\mathrm{P}(2)$ & $t(\operatorname{crit} 2)$ & Significance \\
\hline & LKL 21 & 0.484 & 0.512 & 1.0068 & 0.1658 & 1.76 & 0.3311 & 2.12 & - \\
\hline & LKL 42 & 0.484 & 0.507 & 0.9764 & 0.1727 & 1.76 & 0.345 & 2.12 & - \\
\hline & LKL 49 & 0.484 & 0.41 & 3.0017 & 0.0048 & 1.76 & 0.0095 & 2.12 & $*$ \\
\hline & LKL 58 & 0.484 & 0.337 & 3.6697 & 0.0013 & 1.76 & 0.0025 & 2.12 & $*$ \\
\hline & LKL 60 & 0.484 & 0.417 & -2.312 & 0.0182 & 1.76 & 0.036 & 2.12 & - \\
\hline & LKL 66 & 0.484 & 0.389 & 4.414 & 0.00029 & 1.76 & 0.0006 & 2.12 & $*$ \\
\hline & LKL 96 & 0.484 & 0.437 & 1.7788 & 0.048 & 1.76 & 0.096 & 2.12 & - \\
\hline \multirow{6}{*}{ LKL 21} & LKL 42 & 0.528 & 0.529 & 0.596 & 0.28 & 1.76 & 0.56 & 2.16 & - \\
\hline & LKL 49 & 0.528 & 0.421 & 4.546 & 0.00027 & 1.76 & 0.0005 & 2.16 & $*$ \\
\hline & LKL 58 & 0.528 & 0.348 & 4.5327 & 0.00028 & 1.76 & 0.0006 & 2.16 & $*$ \\
\hline & LKL 60 & 0.528 & 0.426 & 3.546 & 0.00179 & 1.76 & 0.0036 & 2.16 & $*$ \\
\hline & LKL 66 & 0.528 & 0.394 & 3.999 & 0.00075 & 1.76 & 0.0015 & 2.16 & $*$ \\
\hline & LKL 96 & 0.528 & 0.443 & 3.0415 & 0.00473 & 1.76 & 0.0095 & 2.16 & $*$ \\
\hline
\end{tabular}


VI: Testing of significance of differences in mean increase values for plants height of clone 42 and 49 in combination with other clones

\begin{tabular}{|c|c|c|c|c|c|c|c|c|c|}
\hline \multirow{6}{*}{ LKL 42} & clones & $\mathrm{x}(1)$ & $\mathrm{x}(2)$ & $\mathrm{t}$ (stat) & $\mathrm{P}(1)$ & $\mathrm{t}($ crit 1$)$ & $\mathrm{P}(2)$ & $\mathrm{t}($ crit 2$)$ & Significance \\
\hline & LKL 49 & 0.51 & 0.421 & 2.72149 & 0.008731 & 1.76 & 0.0174 & 2.16 & - \\
\hline & LKL 58 & 0.51 & 0.348 & 4.58674 & 0.00025 & 1.76 & 0.0005 & 2.16 & $*$ \\
\hline & LKL 60 & 0.51 & 0.426 & 2.9267 & 0.0059 & 1.76 & 0.017 & 2.16 & $*$ \\
\hline & LKL 66 & 0.51 & 0.394 & 4.3918 & 0.00036 & 1.76 & 0.0073 & 2.16 & $*$ \\
\hline & LKL 96 & 0.51 & 0.443 & 4.2109 & 0.00051 & 1.76 & 0.001 & 2.16 & $*$ \\
\hline \multirow{4}{*}{ KLK 49} & LKL 58 & 0.421 & 0.348 & 2.844 & 0.0069 & 1.76 & 0.0137 & 2.16 & $*$ \\
\hline & LKL 60 & 0.421 & 0.426 & -0.2353 & 0.4087 & 1.76 & 0.817 & 2.16 & - \\
\hline & LKL 66 & 0.421 & 0.394 & 1.012 & 0.1649 & 1.76 & 0.3299 & 2.16 & - \\
\hline & LKL 96 & 0.421 & 0.443 & 0.86 & 0.2027 & 1.76 & 0.405 & 2.16 & - \\
\hline
\end{tabular}

VII : Testing of significance of differences in mean increase values for plants height of clone 58, 60 and 66 in combination with other clones

\begin{tabular}{|c|c|c|c|c|c|c|c|c|c|}
\hline \multirow{4}{*}{ LKL 58} & clones & $\mathrm{x}(1)$ & $\mathrm{x}(2)$ & $\mathrm{t}$ (stat) & $\mathrm{P}(1)$ & $\mathrm{t}($ crit 1$)$ & $\mathrm{P}(2)$ & $\mathrm{t}($ crit 2$)$ & Significance \\
\hline & LKL 60 & 0.348 & 0.426 & 4.4135 & 0.00035 & 1.76 & 0.0007 & 2.16 & $*$ \\
\hline & LKL 66 & 0.348 & 0.394 & 1.2178 & 0.12246 & 1.76 & 0.2449 & 2.16 & - \\
\hline & LKL 96 & 0.348 & 0.443 & 3.8546 & 0.00099 & 1.76 & 0.0019 & 2.16 & $*$ \\
\hline \multirow[t]{2}{*}{ LKL 60} & LKL 66 & 0.426 & 0.394 & 0.9347 & 0.2834 & 1.78 & 0.1834 & 2.16 & - \\
\hline & LKL 96 & 0.426 & 0.443 & 1.255 & 0.714 & 1.78 & 0.1166 & 2.16 & - \\
\hline \multirow{2}{*}{ KLK 66} & & & & & & & & & \\
\hline & LKL 96 & 0.394 & 0.443 & 1.5202 & 0.3169 & 1.77 & 0.076 & 2.17 & - \\
\hline
\end{tabular}

$t$ (crit 1), $t$ (crit 2)-t critical values (critical region), $t$ (stat)- $t$ statistic value, $x$ (1)- mean value of the growth increase of evaluated clone, $x(2)$ - mean value of the growth increase of compared clones, $P$ (1), $P$ (2 - probal levels (range of probability)

\section{DISCUSSION}

Experiments of some authors (Burmistrov, 1985; Cagáňová, 1993) have confirmed a small growth increase of the edible honeysuckle during the first 3 years. Our results supported this knowledge, especially in case of LKL 58 and LKL 66. According to Matuškovič and Miko (2003) the growth increase during 3 years of observations (1999-2001) represented mean value 0.42 meters. Our results with Lonicera kamtschatica clones showed marked differences from these mentioned observations. On the basis of our experiments we can claim a higher values of growth increase in all evaluated clones of Lonicera kamtschatica. In case of LKL 21 it took 2.49 meters (the highest value), in LKL 581.06 meters (the lowest value). The more dynamics growth of Lonicera kamtschatica clones can be considered as a positive trait for the further cultivation. For the Lonicera kamtschatica is characterics a slow growth and it is the key pro- blem of obtaining an interesting yields (Matuškovič, 1999).

Results of Matuškovič and Miko (2003) showed on the statistically significant differences between individual variants of planting (with mulch-without irrigation, without mulch-without irrigation). We suppose that the repeatings in our experiment was not be reflected in statistically significant differences due to uniformity of planting conditions. Studies of Matuškovič (1999) with sort of Lonicera kamtschatica did not confirm the statistical influence of genetic qualities. In contrary with this study genotype played an important role in growth dynamics of Lonicera kamtschatica that is supported by the statistically significant differences between individual clones. The most frequent differences were observed in case of LKL 21 and LKL 58. In the same way our study confirmed the statistical influence of year with very strong effect that is in agreement with the results of Matuškovič (1999). 


\section{SÚHRN}

\section{Hodnotenie dynamiky rastu klonov Lonicera kamtschatica}

V predloženom článku sa zaoberáme s hodnotením rastovej dynamiky vybraného súboru klonov zemolezu kamčatského v podmienkach Nitry. Merania sme uskutočnili dvakrát do roka (na jar a jeseň) počas rokov 2003-2005. V rámci každého klonu bolo hodnotených 5 krov.

Na základe výsledkov meraní môžeme konštatovat’ najväčšie prírastky biomasy v prípade LKL 21, po ňom nasledovali klony LKL 16 a LKL 5. Najnižšie prírastky boli charakteristické pre LKL 58 a LKL 60.

Na základe štatistického hodnotenia výsledkov môžeme ročník považovat’ za štatisticky významný činitel' formujúci rastovú dynamiku krov. Vplyv ročníka je vel'mi silný ( $\left.\varepsilon^{2}=0.96\right)$, zatial' čo vplyv ročníka v interakcii s klonom môžeme hodnotit' ako stredný $\left(\varepsilon^{2}=0.42\right)$.

Klony LKL 21 a LKL 58 sa v najväčšej miere odlišujú od ostatných klonov. V rámci uvedených klonov štatisticky významné rozdiely boli zaznamenané v 7 hodnotených dvojiciach klonov. Rovnako od ostatných klonov sa rastom výrazne odlišuje klon LKL 42.

Na základe uvedených všetkých analýz môžeme z hl'adiska perspektívnosti pestovania zostavit' nasledovné poradie klonov: LKL 21, LKL 16, LKL 5, LKL 42, LKL 49, LKL 96, LKL 6, LKL 60, LKL 66 and LKL 58.

Lonicera kamtschatica, klony, rastová dynamika, ročník, opakovania

\section{REFERENCES}

BURMISTROV, A. D.: Jagodnyje kul'túry. 1. izd. Leningrad: Agromizdat, 1985, 252 s.

CAGÁŇOVÁ, I.: The genus Lonicera L.- a valuable genus resource for new crop. Plant genetic resources. Nitra: SPU, 1993 s. 99-102

JUŠEV, A. A., PLEKHANOVA, M. N.: Samyje lučšije. 1. izd. Sankt Peterburg: Vserossijskij naučnoissledovatel'skij institut rastenijevodstva I. Vavilova, 1997, $122 \mathrm{~s}$.

MATUŠKOVIČ, J.: Agrobiologické možnosti pestovania zemolezu na Slovensku in: Agrobiologické faktory ovplyvňujúce úspešné pestovanie marhúl' a zemelezu kamčatského. 1. vyd. Nitra: SPU, 2003, s. 151-199 ISBN 80-8069-289-0

MATUŠKOVIČ, J., PAULEN, O.: Základy ovocinárstva. 1. vyd. Nitra: Edícia Ochrana biodiverzity, č. publikácie 14, 2001, 137 s. ISBN 80-7137-850-X

MATUŠKOVIČ, J.: An interaction of irrigation Titavin forming the habit of the modelled plant of
Lonicera kamtschatica. Acta horticulturae et regiotecturae, 1999, 2: 36-39

MATUŠKOVIČ, J., MIKO, M.: Influence of agrobiological measurments of unwowen textile and irrigation on growth dynamism of Lonicera kamtschatica. Acta univ.agric.et silvic. Mendel. Brun., 2003, LI, No. 3, pp. 55-62

PLEKHANOVA, M. N.: Lonicera kamtschatica (Sevast.) Pojark. na ostrove Iturup i perspektivy jego ispol'zovanija. Rastitel'nyje ressursy, 1986, 1: 99-106

PLEKHANOVA, M. N.: Blue honeysuckle - a new commercial berry crop for temperature climate. Dresden: Acta Horticulturae 538-Genetic resources and breeding, 2000, vol. 2, No artickle 142

POKORNÁ, T., PODOLÁKOVÁ, K. a MATUŠKOVIČ, J.: Lonicera kamtschatica - a new valuable crop in Slovakia. 3. vedecká konferencia doktorandov konaná pod záštitou dekana FPV s medzinárodnou účastou. Nitra: Edícia Prírodovedec, 2002. s. $273-274$

Address

Prof. Ing. Ján Matuškovič, PhD., Katedra ovocinárstva, vinohradníctva a vinárstva, Slovenská pol'nohospodárska univerzita, Tr. A. Hlinku 2, 94976 Nitra, Slovenská republika, jan.matuskovic@uniag.sk, RNDr. Tünde Pokorná-Juríková, PhD., Katedra odborových didaktík, Univerzita Konštantína Filozofa, Nábrežie mládeže 91, 94974 Nitra, Slovenská republika, tpokorna@ukf.sk 